\title{
Comparison of Two Methods to Evaluate Quantitative Resistance to Eastern Filbert Blight in European Hazelnut
}

\author{
Clarice J. Coyne, ${ }^{1}$ Shawn A. Mehlenbacher, ${ }^{2}$ Kenneth B. Johnson, ${ }^{3}$ John N. Pinkerton, ${ }^{4}$ and \\ David C. Smith ${ }^{5}$ \\ Department of Horticulture, 4017 Agriculture and Life Sciences Bldg., Oregon State University, Corvallis, \\ OR 97331-2911
}

\begin{abstract}
AdDitional INDEX wORDs. Corylus avellana, Anisogramma anomala, disease resistance, filbert, nut breeding
Abstract. A rapid and reliable assay for screening European hazelnut (Corylus avellana L.) genotypes for quantitative resistance to eastern filbert blight [Anisogramma anomala (Peck) E. Müller] was tested by comparing two methods using the same clones. In the first assay, disease spread was followed for five consecutive years (1992-96) in a field plot planted in 1990. Measured responses included disease incidence (the presence or absence of cankers) and total canker length, quantified as the length of perennially expanding cankers. The second assay consisted of annually exposing replicated sets of 2-year-old, potted trees to artificially high doses of pathogen inoculum and measuring incidence and canker lengths at the end of the next growing season. The potted trees were exposed to inoculum in 1990, 1992, 1993, and 1994. Compared to the field plot, disease incidence and total canker length were higher in all the potted-tree experiments. Nonetheless, disease responses of individual clones in the two screening methods were significantly correlated in some contrasts $\left(r_{s}=0.97\right.$ between 1996 field and 1995 potted trees). However, for a few clones ('Camponica', 'Tombul Ghiaghli', and 'Tonda di Giffoni'), disease developed slowly in the field plot, but disease incidence on these clones averaged $>30 \%$ in most of the potted-tree studies. Disease responses also were significantly correlated among some of the potted-tree experiments $\left(r_{s}=0.72\right.$ for the comparison of 1994 to 1995). Highly susceptible and highly resistant hazelnut clones were identified by both methods. However, the field plot method was superior to the potted-treemethod for distinguishing among moderately resistant clones. 'Bulgaria XI-8', ‘Gem', 'Camponica', 'Tombul Ghiaghli', and 'Tonda di Giffoni’ were identified as promising sources of quantitative resistance to eastern filbert blight.
\end{abstract}

The introduced disease, eastern filbert blight (EFB), caused by the fungus Anisogramma anomala, currently threatens European hazelnut (Corylus avellana) production in Oregon (Pinkerton et al., 1992). The predominant cultivar, 'Barcelona' is only moderately resistant, while the second most common cultivar, 'Ennis', is highly susceptible (Cameron, 1976; Pinkerton et al., 1993). Current control recommendations include pruning diseased limbs and applying fungicides two to three times each spring (Johnson et al., 1996). Genetic resistance in new hazelnut cultivars offers the most economical longterm solution (Johnson et al., 1996) and is a goal of the Oregon State University hazelnut breeding program (Mehlenbacher, 1991).

Eastern filbert blight was first reported in the Pacific northwest in 1973 in southwest Washington (Davison and Davidson, 1973) and by 1980 had spread throughout southwest Washington eliminating commercial production (Gottwald and Cameron, 1980). Eastern filbert blight was first found in Oregon's major production areas in 1986 (Pinkerton et al., 1992) and the epidemic continues to spread southward through Oregon's Willamette Valley (Pinkerton et al., 1998a).

Received for publication 9 June 1998. Accepted for publication 28 Apr. 2000. Technical paper 11354 of the Oregon Agricultural Experiment Station. This research was supported by funds from the Oregon Hazelnut Commission and USDA-CSRS special grant 91-34242-5922. The cost of publishing this paper was defrayed in part by the payment of page charges. Under postal regulations, this paper therefore must be hereby marked advertisement solely to indicate this fact. ${ }^{1}$ Former graduate student. Current address: U.S. Department of Agriculture, Agricultural Research Service, 59 Johnson Hall, Washington State University, Pullman, WA 99164-6402.

${ }^{2}$ Professor.

${ }^{3}$ Professor, Dept. of Botany and Plant Pathology, Oregon State University, Corvallis, OR 97331

${ }^{4}$ Research plant pathologist, U.S. Department of Agriculture, Agricultural Research Service, Horticulture Crops Laboratory, Corvallis, OR 97331.

${ }^{5}$ Senior research assistant.
Infection of hazelnut shoots by A. anomala occurs from budbreak in early March through the end of April ( Johnson et al., 1994; Stone et al., 1992). The disease is spread by windborne spores and spore release is environmentally dependent (Pinkerton et al., 1998a). The timing and amount of precipitation were most important in accounting for differences in year-to-year variability in spore discharge patterns (Pinkerton et al., 1998b). Environment also influences seasonal spore availability, spore release, and spore survival/infection on the host (J.N. Pinkerton, personal communication). Cankers with stromata usually develop 14 to 16 months after first infection, with some not developing until 22 to 24 months after infection (Johnson et al., 1996; Stone et al., 1992). Cankers will expand perennially to girdle limbs, killing mature trees in 4 to 10 years, depending on the cultivar (Gottwald and Cameron, 1980; Pinkerton et al., 1998a).

Complete genetic resistance to EFB was first identified in the pollenizer 'Gasaway' (Cameron, 1976) with resistance being conferred by a single dominant gene (Coyne et al., 1998; Mehlenbacher et al., 1991). Hazelnut cultivars lacking the 'Gasaway' resistance gene vary quantitatively in their degree of susceptibility to eastern filbert blight (Pinkerton et al., 1993). Quantitative resistance to EFB is controlled by additive gene action, with heritabilities estimated to be $0.21,0.39$, and 0.47 for disease incidence, number of cankers, and proportion of wood diseased, respectively (Osterbauer et al., 1997).

An enzyme-linked immunosorbent assay is available to identify progeny carrying the 'Gasaway' resistance gene for rapid and reliable greenhouse screening (Coyne et al., 1996). However, the assay does not identify quantitative resistance. No A. anomala isolates collected from Oregon or the east coast were able to overcome the 'Gasaway' resistance (Osterbauer, 1996). DNA variability in the pathogen (Osterbauer, 1996) indicates quantitative resistance is highly desirable (Simmonds, 1983). The time required to incorporate quantitative disease resistance data can be significant (Hansche, 1983).Eastern filbert blight requires 2 years for symptom 
expression, and hazelnut requires a minimum of 16 years from the initial cross to the release of a new cultivar.

A better method is needed to identify sources of quantitative resistance for introgression into the breeding program(Mehlenbacher, 1991). We examined two assays with the same genotypes to evaluate quantitative resistance in hazelnut selections to EFB. The first method relied on natural field inoculation and allowed disease to develop in a replicated field plot over 7 years. The second method exposed replicated potted trees to artificial inoculation and resistance was evaluated after 2 years (Pinkerton et al., 1993). In this paper, we examine (1) 5 years of disease progress in a field plot, (2) compare four separate potted-tree experiments conducted annually, and (3) compare the ranking of the same clones from the 2-year potted-tree assays with the field plot in determining levels of quantitative resistance.

\section{Materials and Methods}

Field STUdy. A field plot of 32 genotypes was planted in a randomized complete block design on 23 Mar. 1990 at the Washington State University Vancouver Research Experiment Center (WSUVREC), Vancouver, Wash. Self-rooted clonal selections propagated by mound layering (Westwood, 1993) were planted (Table 1). For each genotype, nine trees were planted in three-tree plots in each of three blocks. Trees were spaced $0.9 \mathrm{~m}$ apart in the rows with 0.9 m between rows. Each block had two rows of 48 trees each. Between blocks and on all four sides of the plot, trees of susceptible cultivars ('Ennis' and 'Butler') were planted to provide inoculum of A. anomala. Every third tree in these inoculum rows had been exposed to EFB previously in a diseased nursery. The plot was maintained with summer sprinkler irrigation, annual broadcast applications of urea fertilizer $(46 \mathrm{~N}-0 \mathrm{P}-0 \mathrm{~K})$ at a rate of 168 $\mathrm{kg} \cdot \mathrm{ha}^{-1}$, weed control with herbicides, and removal of suckers. The relative amount of inoculum of $A$. anomala was monitored by placing two rain-catch type spore traps in the field plot (Pinkerton et al., 1993). Collection reservoirs for the spore traps were changed monthly from March to May 1992 and 1993. The inoculum rows were removed at the end of fifth growing season (Winter 1994).

FiELd STUDY DATA COLLECTION. Evaluations of canker incidence (percentage of trees infected in each plot) and total canker length in centimeters of each tree on field planted genotypes were recorded after leaf abscission in the winter to facilitate identification and measurement of cankers. Field disease data were collected in the winters following the 1991, 1992, 1993, 1994, and 1995 growing seasons. Data for each tree were trunk diameter $(\mathrm{cm}) 25 \mathrm{~cm}$ above the soil line, number of cankers, and total length of all cankers. Cankers were color flagged each year to assist in year-to-year identification and measurement. The fourth year (1995 data) of data collection required estimation of some of the canker lengths due to tree height. In the fifth (1996 data) and final year of data collection, trees were felled at the time of canker measurement.

PotTed-Tree EXPERIMents. Rooted layers (Westwood, 1993) of European hazelnut genotypes were obtained from the Oregon State University hazelnut breeding program nursery. Trees were grown one season in nursery rows located in Corvallis, Ore. where EFB has not been found, and placed in cold storage until use. Trees were potted in February at WSUVREC in 7-L pots with a medium of 1 peat : 1 pumice : 1 fine bark dust douglas fir [Pseudotsuga menziesii (Mirb.) Franco] bark shredded and screened through a $1.9-\mathrm{cm}$ screen (by volume) supplemented with $18 \mathrm{~g} 18 \mathrm{~N}-2.6 \mathrm{P}-9.9 \mathrm{~K}$ Osmocote fertilizer (Scotts-Sierra Horticultural Products Co., Marysville, Ohio). Potted trees were exposed to inoculum by placement under wire mesh platforms topped with diseased hazelnut branches (Pinkerton et al., 1993). A randomized complete block design was used with an average of four trees of each genotype under each of the three wire mesh platforms (blocks) for a total of 12 trees per genotype. The first potted-tree experiment was exposed to inoculum March to May 1990 (47 genotypes), the second in March to June 1992 (46 genotypes) and again in March to June 1993; the third from March to June 1993 (67 genotypes), and the fourth pottedtree experiment from Mar. to June 1994 (65 genotypes). The four potted-tree experiments had the following number of genotypes in common with the field study: 29 (1990), 6 (1993), 23 (1994), and 9 (1995). The release of inoculum of $A$. anomala from hazelnut branches on the wire mesh platforms was facilitated by an overhead sprinkler irrigation (Pinkerton et al., 1993). Rain catch-type spore traps were placed under the platforms to monitor the relative amount of inoculum deposited onto the trees. After exposure, the trees were maintained in pots over the summer and then field planted in the fall. Following planting, the trees were fertilized and irrigated until evaluation of disease in fall or winter of the next year.

POTTED-TREE EXPERIMENTS DATA COLLECTION. Disease responses measured in the potted-tree experiments were the same as in the field study. Due to winter injury in 1990, disease incidence and severity evaluations of Pinkerton et al. (1993) were made by stripping bark from the trunks in Apr. 1991 and measuring the cambial necrosis length in centimeters (Stone et al., 1992).

Data ANALYsis. Disease responses of each genotype were subjected to analysis of variance (ANOVA) for each of the 5 years of field data and the 4 years of potted-tree studies (SAS Inst., Inc., 1990). Disease incidence was calculated as the percentage of trees infected in each plot (block). Similarly, total canker length was determined for each genotype by adding the lengths of the individual cankers from each tree and averaging by genotype within each block. To determine the most appropriate data transformation, twoway ANOVA of canker length was performed initially on 1) average total canker length (ATCL), 2) square root of ATCL, 3) log of ATCL, 4) ATCL/trunk cross-sectional area (TCA), 5) log of ATCL/ TCA, and 6) square root of ATCL/TCA. Square root transformation was selected as the most appropriate transformation to equalize the variance across means. Henceforth, square root of average total canker length will be known as TCL. In the field study, only 29 of the 32 genotypes were included in the development of ANOVA models due to poor establishment of three genotypes. In the fifth year of the field study, eight dead or nearly dead genotypes (OSU 023.017, OSU 183.060, 'Cosford', 'Daviana', 'Ennis', 'Neue Riesennuss', 'Rode Zeller', and 'Tonda Romana') were excluded from the analysis because disease development had stopped on these genotypes. Small and weak trees $(<0.8 \mathrm{~cm}$ diameter) were removed from the analyses of the potted-tree studies. Genotype means were tabulated and compared with Fisher's protected least significant difference (LSD) at $P=0.05$ (SAS Inst., Inc., 1988).

COMPARISON OF SCREENING METHODS. A correlation matrix of the four potted-tree experiments and all 5 years of the field study was calculated for the genotype responses of disease incidence and TCL based on Spearman's coefficient of rank correlation (SAS Institute, Inc., 1990, 1990; Steel and Torrie, 1980). Each correlation was calculated using only those genotypes that were common to the two experiments being compared. Least squares means were used for ranking the genotypes because experimental units were unbalanced due to dead trees in the field plot and unequal numbers of potted trees per block in each potted-tree experiment. Regression models were developed for comparison of disease responses from the potted-tree experiments with each year of disease data from the field study. 
Means for the genotypes in the various tests were plotted and examined for outliers, i.e., genotypes for which the relative disease response varied between the two methods (SAS Institute, Inc., 1990).

\section{Results}

Statistical TREATMENT. The square root transformation of least square mean total canker length (TCL) increased the independence between mean and variance better than adjusting the scores for tree size using trunk cross sectional area with the field plot data, and was nearly identical to $\log$ transformation. However, the square root transformation was superior to log transformation of potted-tree data. Thus, square root transformation was selected as a consistent scale for comparing the two assays. Square root transformation also provided higher coefficient of determination $\left(R^{2}\right)$ and decreased coefficient of variation values. Total number of cankers was not statistically useful in determining quantitative resistance to EFB in hazelnut in these studies (data not presented).
FIELD STUDY. Disease incidence and TCL increased each year in most genotypes (Table 1). The variation in the rate of increase of disease incidence and the extent of TCL between genotypes indicates a range of EFB resistance in hazelnut (Table 1). Canker length across hazelnut genotypes varied significantly in all years (Table 1). Correlations of TCL in each year of the field study with each of the other years were all highly significant (Table 2). Good separation of genotypes was evident in the 1995 data (Table 1) and was very apparent by the fifth year of the epidemic (1996 data). Susceptible and resistant genotypes were identified in the sixth year of the field plot experiment (1995 data).

POTTED-TREE EXPERIMENTS. The 1994 potted-tree experiment had the highest disease incidence with $85 \%$ of the 67 genotypes having all trees infected (Table 3 and data not presented). TCL of the potted-tree studies of 1990, 1993, and 1995 were significantly correlated with those in the 1994 study. However, not all correlations between potted-tree assays were significant (Table 2). For example, results for 1995 were not correlated to those for 1990 or

Table 1. Disease incidence and total canker length (TCL) of eastern filbert blight on European hazelnut genotypes planted in the field from 1990 to 1996 near Vancouver, Wash.

\begin{tabular}{|c|c|c|c|c|c|c|c|c|c|c|}
\hline \multirow[b]{2}{*}{ Genotype } & \multicolumn{5}{|c|}{ Disease incidence $(\%)^{\mathrm{z}}$} & \multicolumn{5}{|c|}{ Total canker length $(\mathrm{cm})^{\mathrm{y}}$} \\
\hline & 1992 & 1993 & 1994 & 1995 & 1996 & 1992 & 1993 & 1994 & 1995 & 1996 \\
\hline OSU 183.060 & 11 & 100 & 100 & 100 & 100 & 0.4 & 8.6 & 12.4 & 26.6 & $\mathrm{NE}^{\mathrm{x}}$ \\
\hline Ennis & 11 & 89 & 100 & 100 & 100 & 0.5 & 7.0 & 9.7 & 23.5 & $---{ }^{w}$ \\
\hline OSU 023.017 & 22 & 100 & 100 & 100 & 100 & 0.9 & 6.0 & 9.4 & 21.3 & -- \\
\hline Neue Riesennuss & 22 & 67 & 100 & 100 & 100 & 0.9 & 4.1 & 8.6 & 18.0 & --- \\
\hline Tonda Romana & 11 & 78 & 100 & 100 & 100 & 0.4 & 4.6 & 8.5 & 25.7 & --- \\
\hline Daviana & 11 & 78 & 89 & 100 & 100 & 0.4 & 3.4 & 8.3 & 18.4 & --- \\
\hline Cosford & 55 & 89 & 100 & 100 & 100 & 2.2 & 5.7 & 8.1 & 13.4 & $\mathrm{NE}^{\mathrm{w}}$ \\
\hline Rode Zeller & 11 & 44 & 100 & 100 & 100 & 0.3 & 2.4 & 6.7 & 14.6 & --- \\
\hline Brixnut & 0 & 33 & 50 & 100 & 100 & 0.0 & 2.4 & 5.5 & 19.0 & 23.0 \\
\hline OSU 039.044 & 0 & 33 & 50 & 100 & 100 & 0.0 & 1.8 & 3.1 & 16.6 & 25.8 \\
\hline Casina & 6 & 39 & 61 & 100 & 100 & 0.3 & 1.8 & 3.5 & 16.0 & 28.7 \\
\hline Negret & 22 & 44 & 67 & 100 & 100 & 0.5 & 2.0 & 4.4 & 15.0 & 28.2 \\
\hline TGDL & 11 & 61 & 61 & 100 & 100 & 0.3 & 2.9 & 4.3 & 14.8 & 21.1 \\
\hline OSU 175.123 & 0 & 33 & 44 & 100 & 100 & 0.0 & 1.4 & 2.5 & 12.0 & 19.0 \\
\hline Giresun 054.001 & 0 & 22 & 33 & 100 & 100 & 0.0 & 1.0 & 1.8 & 11.1 & 18.2 \\
\hline Creswell & 0 & 11 & 11 & 89 & 100 & 0.0 & 0.5 & 1.0 & 11.1 & 18.7 \\
\hline Montebello & 0 & 22 & 33 & 100 & 100 & 0.0 & 1.1 & 1.9 & 11.0 & 18.8 \\
\hline Nooksack & 0 & 33 & 50 & 89 & 100 & 0.0 & 1.6 & 3.9 & 10.2 & 18.4 \\
\hline Barcelona & 0 & 0 & 27 & 94 & 100 & 0.0 & 0.0 & 2.3 & 10.0 & 20.4 \\
\hline Ribet & 0 & 11 & 33 & 100 & 100 & 0.0 & 0.4 & 1.6 & 9.8 & 18.0 \\
\hline OSU 041.083 & 0 & 22 & 44 & 100 & 100 & 0.0 & 0.9 & 2.7 & 8.5 & 16.7 \\
\hline OSU 179.061 & 0 & 0 & 0 & 100 & 100 & 0.0 & 0.0 & 0.0 & 9.3 & 16.0 \\
\hline Henneman \#3 & 0 & 33 & 50 & 89 & 100 & 0.0 & 1.7 & 3.1 & 7.2 & 14.9 \\
\hline Hall's Giant & 0 & 22 & 33 & 78 & 100 & 0.0 & 0.9 & 1.9 & 5.9 & 13.3 \\
\hline Segorbe & 11 & 11 & 11 & 56 & 100 & 0.6 & 0.6 & 1.1 & 3.8 & 10.3 \\
\hline Italian Red & 0 & 11 & 11 & 67 & 78 & 0.0 & 0.5 & 1.0 & 4.2 & 9.4 \\
\hline Willamette & 0 & 0 & 0 & 56 & 83 & 0.0 & 0.0 & 0.0 & 3.9 & 9.3 \\
\hline Bulgaria XI-8 & 0 & 11 & 11 & 33 & 44 & 0.0 & 0.5 & 0.8 & 1.9 & 4.4 \\
\hline Gem & 0 & 11 & 11 & 11 & 44 & 0.0 & 0.2 & 0.3 & 0.8 & 2.4 \\
\hline Camponica & 0 & 0 & 0 & 0 & 33 & 0.0 & 0.0 & 0.0 & 0.0 & 1.4 \\
\hline Tombul Ghiaghli & 0 & 0 & 0 & 0 & 22 & 0.0 & 0.0 & 0.0 & 0.0 & 1.1 \\
\hline Tonda di Giffoni & 0 & 0 & 0 & 0 & 0 & 0.0 & 0.0 & 0.0 & 0.0 & 0.0 \\
\hline Gasaway & 0 & 0 & 0 & 0 & 0 & 0.0 & 0.0 & 0.0 & 0.0 & 0.0 \\
\hline $\mathrm{LSD}_{0.05}$ & 23 & 40 & 37 & 28 & 27 & 1.6 & 4.2 & 5.8 & 8.7 & 12.3 \\
\hline
\end{tabular}

${ }^{\mathrm{Z}}$ Disease incidence calculated as percentage trees with cankers in each three-tree plot and averaged over the three blocks.

yTotal canker length (TCL) is the least-squares mean calculated from square root transformed total canker length.

${ }^{\mathrm{x}} \mathrm{NE}=$ no estimate, less than three trees alive in more than one block.

wTotal canker length was not a reliable indicator with highly susceptible genotypes in 1996 as most trees were nearly dead. 
1993 (Table 2). Disease incidence demonstrates similar significant correlations for those genotypes in common among potted-tree experiments. Correlations of 1990 subcambial discoloration and TCA in the 1993, 1994, and 1995 potted-tree studies were positive, but only one was significant (Table 2).

COMPARISONS OF THE FIELD STUDY AND POTTED-TREE EXPERIMENTS. Cankers appeared sooner, incidence was higher, and the ultimate EFB severity appeared more pronounced in the four pottedtree experiments (Table 3 ). Ascospore trap counts of the potted trees had spore concentrations at least 240 times higher than traps in the field plot during 1993 and 1994 (Table 4). Disease incidence and TCL were significantly correlated between the last 3 years of the field plot and all the potted-tree experiments (Table 2). TCL of the 1994 potted-tree experiment with the final year of the field study (1996) and with potted trees from 1995, exhibited a strong relationship between the two methods, $r_{s}=0.97$ and $r_{s}=0.72$, respectively.

Correlation of genotype TCL among the field study and the potted-tree experiments were significant (Table 2), but there were differences between the assays. For example, 'Barcelona', 'Tombul Ghiaghli', and 'Willamette' had no disease in the first and second year of data collection in the field plot, while first year disease incidence averaged over $70 \%$ in the 1990, 1993, and 1994 pottedtree studies (Table 3). Two clones, 'Tombul Ghiaghli' and 'Willamette', also remained free of cankers until the fourth year of the field study (Table 1). OSU 179.061 was the most susceptible genotype in the 1994 potted tree exposure (Table 3), yet developed no disease in the field study during the first 3 years, and was ranked more resistant than most of the genotypes at the end of the field study (Table 1). In the 1990 potted-tree experiment, two clones, 'Tombul Ghiaghli' and 'Tonda Gentile delle Langhe', were more susceptible than in the field study (Tables 1 and 3).

'Barcelona', 'Tombul Ghiaghli', and 'Willamette' were ranked similarly in the field plot and in two of the three potted-tree experiments. Three cultivars, 'Ennis', 'Casina', and 'Daviana', had more disease in the field by the third year than predicted from the potted-tree studies as measured after 1 year (Tables 1 and 3). Disease was slower to develop in the field study, as illustrated by 'Ennis' and 'Casina' under the lower inoculum density (Table 4). Five genotypes, 'Hall's Giant', 'Segorbe', 'Willamette', OSU179.061, and 'Tombul Ghiaghli', had less disease in the field than predicted from the higher inoculum regime found in the potted-tree studies (Table 4).

Table 2. Correlations of the responses of European hazelnut genotypes to eastern filbert blight over 5 years in a continuous field experiment and four annual exposures of potted trees to artificially high doses of pathogen inoculum. Spearman's coefficient of rank correlation $\left(r_{s}\right)$ presented are for square root transformed least-square mean of total canker length (TCL) (above diagonal) and incidence of diseased trees (percentage infected trees) (below diagonal).

\begin{tabular}{|c|c|c|c|c|c|c|c|c|c|}
\hline \multirow[b]{2}{*}{ Expt. } & \multicolumn{5}{|c|}{ Field plot } & \multicolumn{4}{|c|}{ Potted trees } \\
\hline & 1992 & 1993 & 1994 & 1995 & 1996 & 1990 & 1993 & 1994 & 1995 \\
\hline \multicolumn{10}{|l|}{ Field plot } \\
\hline 1992 & --- & $\begin{array}{c}r_{s}=0.67 \\
0.0001^{\mathrm{z}} \\
\mathrm{n}=33^{\mathrm{y}}\end{array}$ & $\begin{array}{c}r_{s}=0.63 \\
0.0001 \\
\mathrm{n}=33\end{array}$ & $\begin{array}{c}r_{s}=0.58 \\
0.0001 \\
\mathrm{n}=33\end{array}$ & $\begin{array}{c}r_{s}=0.63 \\
0.0001 \\
\mathrm{n}=33\end{array}$ & $\begin{array}{c}r_{s}=0.22 \\
0.15 \\
\mathrm{n}=29\end{array}$ & $\begin{array}{c}r_{s}=0.78 \\
0.07 \\
\mathrm{n}=6\end{array}$ & $\begin{array}{c}r_{s}=0.55 \\
0.0062 \\
\mathrm{n}=23\end{array}$ & $\begin{array}{c}r_{s}=0.73 \\
0.026 \\
\mathrm{n}=9\end{array}$ \\
\hline 1993 & $\begin{array}{c}r_{s}=0.77 \\
0.0001 \\
\mathrm{n}=33\end{array}$ & --- & $\begin{array}{c}r_{s}=0.96 \\
0.0001 \\
\mathrm{n}=33\end{array}$ & $\begin{array}{c}r_{s}=0.89 \\
0.0001 \\
\mathrm{n}=33\end{array}$ & $\begin{array}{c}r_{s}=0.87 \\
0.0001 \\
\mathrm{n}=33\end{array}$ & $\begin{array}{c}r_{s}=0.46 \\
0.01 \\
\mathrm{n}=29\end{array}$ & $\begin{array}{c}r_{s}=0.94 \\
0.0051 \\
\mathrm{n}=6\end{array}$ & $\begin{array}{c}r_{s}=0.55 \\
0.0067 \\
\mathrm{n}=23\end{array}$ & $\begin{array}{c}r_{s}=0.67 \\
0.048 \\
\mathrm{n}=9\end{array}$ \\
\hline 1994 & $\begin{array}{c}r_{s}=0.71 \\
0.0001 \\
\mathrm{n}=33\end{array}$ & $\begin{array}{c}r_{s}=0.95 \\
0.0001 \\
\mathrm{n}=33\end{array}$ & --- & $\begin{array}{c}r_{s}=0.90 \\
0.0001 \\
\mathrm{n}=33\end{array}$ & $\begin{array}{c}r_{s}=0.91 \\
0.0001 \\
\mathrm{n}=33\end{array}$ & $\begin{array}{c}r_{s}=0.52 \\
0.0041 \\
\mathrm{n}=29\end{array}$ & $\begin{array}{c}r_{s}=0.93 \\
0.0077 \\
\mathrm{n}=6\end{array}$ & $\begin{array}{c}r_{s}=0.54 \\
0.009 \\
\mathrm{n}=23\end{array}$ & $\begin{array}{c}r_{s}=0.90 \\
0.001 \\
\mathrm{n}=9\end{array}$ \\
\hline 1995 & $\begin{array}{c}r_{s}=0.47 \\
0.0058 \\
\mathrm{n}=33\end{array}$ & $\begin{array}{c}r_{s}=0.77 \\
0.0001 \\
\mathrm{n}=33\end{array}$ & $\begin{array}{c}r_{s}=0.96 \\
0.0001 \\
\mathrm{n}=33\end{array}$ & --- & $\begin{array}{c}r_{s}=0.52 \\
0.0001 \\
\mathrm{n}=33\end{array}$ & $\begin{array}{c}r_{s}=0.94 \\
0.0036 \\
\mathrm{n}=29\end{array}$ & $\begin{array}{c}r_{s}=0.54 \\
0.0048 \\
\mathrm{n}=6\end{array}$ & $\begin{array}{c}r_{s}=0.95 \\
0.0083 \\
\mathrm{n}=23\end{array}$ & $\begin{array}{c}r_{s}=0.73 \\
0.0001 \\
\mathrm{n}=9\end{array}$ \\
\hline 1996 & $\begin{array}{c}r_{s}=0.41 \\
0.0178 \\
\mathrm{n}=33\end{array}$ & $\begin{array}{c}r_{s}=0.64 \\
0.0001 \\
\mathrm{n}=33\end{array}$ & $\begin{array}{c}r_{s}=0.70 \\
0.0001 \\
\mathrm{n}=33\end{array}$ & $\begin{array}{c}r_{s}=0.84 \\
0.0001 \\
\mathrm{n}=33\end{array}$ & --- & $\begin{array}{c}r_{s}=0.51 \\
0.0046 \\
\mathrm{n}=29\end{array}$ & $\begin{array}{c}r_{s}=0.94 \\
0.0048 \\
\mathrm{n}=6\end{array}$ & $\begin{array}{c}r_{s}=0.58 \\
0.0040 \\
\mathrm{n}=23\end{array}$ & $\begin{array}{c}r_{s}=0.97 \\
0.0001 \\
\mathrm{n}=9\end{array}$ \\
\hline \multicolumn{10}{|c|}{ Potted trees } \\
\hline $1990^{x}$ & $\begin{array}{c}r_{s}=0.56 \\
0.0014 \\
\mathrm{n}=29\end{array}$ & $\begin{array}{c}r_{s}=0.70 \\
0.0001 \\
\mathrm{n}=29\end{array}$ & $\begin{array}{c}r_{s}=0.66 \\
0.0001 \\
\mathrm{n}=29\end{array}$ & $\begin{array}{c}r_{s}=0.64 \\
0.0002 \\
\mathrm{n}=29\end{array}$ & $\begin{array}{c}r_{s}=0.54 \\
0.0025 \\
\mathrm{n}=29\end{array}$ & --- & $\begin{array}{c}r_{s}=0.32 \\
0.307 \\
\mathrm{n}=12\end{array}$ & $\begin{array}{c}r_{s}=0.44 \\
0.0279 \\
\mathrm{n}=25\end{array}$ & $\begin{array}{c}r_{s}=0.23 \\
0.26 \\
\mathrm{n}=12\end{array}$ \\
\hline 1993 & $\begin{array}{c}r_{s}=0.48 \\
0.34 \\
\mathrm{n}=6\end{array}$ & $\begin{array}{c}r_{s}=0.65 \\
0.1653 \\
\mathrm{n}=6\end{array}$ & $\begin{array}{c}r_{s}=0.82 \\
0.0441 \\
\mathrm{n}=6\end{array}$ & $\begin{array}{c}r_{s}=0.86 \\
0.029 \\
\mathrm{n}=6\end{array}$ & $\begin{array}{c}r_{s}=1.00 \\
0.0001 \\
\mathrm{n}=6\end{array}$ & $\begin{array}{c}r_{s}=0.61 \\
0.0338 \\
\mathrm{n}=12\end{array}$ & --- & $\begin{array}{c}r_{s}=0.60 \\
0.0066 \\
\mathrm{n}=19\end{array}$ & $\begin{array}{c}r_{s}=0.45 \\
0.2242 \\
\mathrm{n}=9\end{array}$ \\
\hline 1994 & $\begin{array}{c}r_{s}=0.50 \\
0.015 \\
\mathrm{n}=23\end{array}$ & $\begin{array}{c}r_{s}=0.64 \\
0.001 \\
\mathrm{n}=23\end{array}$ & $\begin{array}{c}r_{s}=0.71 \\
0.0001 \\
\mathrm{n}=23\end{array}$ & $\begin{array}{c}r_{s}=0.85 \\
0.0001 \\
\mathrm{n}=23\end{array}$ & $\begin{array}{c}r_{s}=0.92 \\
0.0001 \\
\mathrm{n}=23\end{array}$ & $\begin{array}{c}r_{s}=0.61 \\
0.0013 \\
\mathrm{n}=25\end{array}$ & $\begin{array}{c}r_{s}=0.22 \\
0.37 \\
\mathrm{n}=19\end{array}$ & --- & $\begin{array}{c}r_{s}=0.72 \\
0.0004 \\
\mathrm{n}=20\end{array}$ \\
\hline 1995 & $\begin{array}{c}r_{s}=0.54 \\
0.1345 \\
\mathrm{n}=9\end{array}$ & $\begin{array}{c}r_{s}=0.73 \\
0.0257 \\
\mathrm{n}=9\end{array}$ & $\begin{array}{c}r_{s}=0.75 \\
0.021 \\
\mathrm{n}=9\end{array}$ & $\begin{array}{c}r_{s}=0.82 \\
0.0068 \\
\mathrm{n}=9\end{array}$ & $\begin{array}{c}r_{s}=0.78 \\
0.0121 \\
\mathrm{n}=9\end{array}$ & $\begin{array}{c}r_{s}=0.35 \\
0.25 \\
\mathrm{n}=12\end{array}$ & $\begin{array}{c}r_{s}=0.35 \\
0.35 \\
\mathrm{n}=9\end{array}$ & $\begin{array}{c}r_{s}=0.78 \\
0.0001 \\
\mathrm{n}=20\end{array}$ & --- \\
\hline
\end{tabular}

${ }^{\mathrm{z} C a l c u l a t e d} P$ values $r_{s}$.

y Number of genotypes ( 9 trees/genotype in the field plot and 12 trees/genotype in each potted tree experiment) included in each comparison.

${ }^{x}$ Data from Pinkerton et al., 1993. 


\section{Discussion}

Data indicate that the potted-tree assay can be useful for reliable and rapid identification of sources of quantitative resistance to eastern filbert blight in European hazelnut. The correlation between the field study and potted tree method indicated general agreement of the results of the two methods of assessing coarse levels of resistance. The principal advantage of the potted-tree method is the

Table 3. Disease incidence and total canker length (TCL) of eastern filbert blight on European hazelnut genotypes used in the annual potted-tree experiments in 1990, 1993, 1994, and 1995 near Vancouver, Wash.

\begin{tabular}{|c|c|c|c|c|c|c|c|c|}
\hline \multirow[b]{2}{*}{ Genotype } & \multicolumn{2}{|c|}{$1990^{2}$} & \multicolumn{2}{|c|}{1993} & \multicolumn{2}{|c|}{1994} & \multicolumn{2}{|c|}{1995} \\
\hline & $\begin{array}{c}\text { Disease } \\
\text { incidence } \\
(\%)^{y}\end{array}$ & $\begin{array}{l}\text { Proportion } \\
\text { of wood } \\
\text { cankered }\end{array}$ & $\begin{array}{c}\text { Disease } \\
\text { incidence } \\
(\%)\end{array}$ & $\begin{array}{c}\text { Total } \\
\text { canker } \\
\text { length } \\
(\mathrm{cm})^{\mathrm{x}}\end{array}$ & $\begin{array}{c}\text { Disease } \\
\text { incidence } \\
(\%)\end{array}$ & $\begin{array}{c}\text { Total } \\
\text { canker } \\
\text { length } \\
(\mathrm{cm})\end{array}$ & $\begin{array}{c}\text { Disease } \\
\text { incidence } \\
(\%)\end{array}$ & $\begin{array}{c}\text { Total } \\
\text { canker } \\
\text { length } \\
(\mathrm{cm})\end{array}$ \\
\hline OSU 179.061 & --- & --- & --- & --- & 100 & 15.6 & --- & --- \\
\hline Negret & 55 & 0.07 & 100 & 6.2 & 100 & 14.2 & --- & --- \\
\hline OSU 183.060 & --- & --- & 100 & 7.4 & 100 & 13.0 & --- & --- \\
\hline OSU 175.123 & --- & --- & --- & --- & 100 & 12.9 & --- & --- \\
\hline Cosford & 83 & 0.11 & --- & --- & 100 & 13.7 & --- & --- \\
\hline Daviana & 85 & 0.40 & --- & --- & 100 & 12.3 & --- & --- \\
\hline OSU 023.017 & 100 & 0.02 & --- & --- & --- & --- & --- & --- \\
\hline OSU 316.139 & --- & --- & --- & --- & 100 & 13.4 & 100 & 9.3 \\
\hline Giresun 054.039 & 44 & 0.04 & 100 & 6.7 & 100 & 12.9 & 100 & 9.3 \\
\hline Montebello & 91 & 0.17 & --- & --- & 100 & 11.8 & --- & --- \\
\hline OSU 361.081 & --- & --- & --- & --- & 100 & 11.8 & 92 & 6.8 \\
\hline Rode Zeller & 92 & 0.26 & --- & --- & --- & --- & --- & --- \\
\hline OSU 311.137 & --- & --- & --- & --- & 100 & 11.6 & 100 & 13.6 \\
\hline Hall's Giant & 74 & 0.09 & 100 & 5.2 & 100 & 11.1 & 100 & 8.2 \\
\hline Neue Riesennuss & 100 & 0.19 & --- & --- & --- & --- & --- & --- \\
\hline Brixnut & 88 & 0.22 & --- & --- & 100 & 10.8 & --- & --- \\
\hline OSU 311.080 & --- & --- & --- & --- & 100 & 10.7 & 100 & 9.3 \\
\hline OSU 278.008 & --- & --- & --- & --- & 100 & 10.2 & 100 & 7.7 \\
\hline Ennis & 80 & 0.18 & --- & --- & 100 & 9.8 & 100 & 12.4 \\
\hline Casina & 63 & 0.13 & --- & --- & 100 & 9.5 & 100 & 9.8 \\
\hline Nooksack & 83 & 0.06 & --- & --- & --- & --- & --- & --- \\
\hline Barcelona & 60 & 0.13 & 100 & 4.4 & 100 & 9.3 & 92 & 9.2 \\
\hline Giresun 054.041 & --- & --- & 54 & 1.6 & --- & --- & 100 & 8.9 \\
\hline Italian Red & 41 & 0.06 & --- & --- & --- & --- & 100 & 8.8 \\
\hline Giresun 054.060 & --- & --- & 100 & 6.3 & --- & --- & 100 & 8.2 \\
\hline Willamette & 72 & 0.10 & 92 & 4.1 & 96 & 9.7 & 92 & 6.7 \\
\hline Segorbe & 55 & 0.05 & --- & --- & 100 & 9.6 & --- & --- \\
\hline Tonda Romana & 100 & 0.38 & --- & --- & 100 & 9.3 & --- & --- \\
\hline OSU 325.091 & --- & --- & --- & --- & 100 & 9.3 & 85 & 6.8 \\
\hline Ribet & 41 & 0.04 & --- & --- & 100 & 9.2 & --- & --- \\
\hline Tonda Gentile delle Langhe & 100 & 0.34 & --- & --- & 100 & 8.1 & --- & --- \\
\hline OSU 054.001 & 0 & 0.09 & --- & --- & --- & --- & --- & --- \\
\hline Creswell & 16 & 0.02 & --- & --- & 91 & 8.2 & --- & --- \\
\hline OSU 296.048 & --- & --- & --- & --- & 72 & 7.5 & 92 & 5.4 \\
\hline OSU 276.076 & --- & --- & --- & --- & 100 & 7.4 & 100 & 9.1 \\
\hline Giresun 054.021 & 0 & 0.00 & 67 & 1.8 & 100 & 7.1 & 100 & 7.5 \\
\hline Lewis & --- & --- & 75 & 3.4 & 100 & 6.1 & --- & --- \\
\hline OSU 296.082 & --- & --- & 92 & 5.4 & 75 & 5.3 & 92 & 6.1 \\
\hline Giresun 054.056 & 0 & 0.00 & --- & --- & 86 & 4.3 & 33 & 3.8 \\
\hline Tombul Ghiaghli & 75 & 0.22 & --- & --- & 83 & 5.8 & 82 & 3.2 \\
\hline OSU $041.083^{\circ}$ & 25 & 0.24 & --- & --- & --- & --- & --- & --- \\
\hline Camponica & 25 & 0.03 & --- & --- & 23 & 0.2 & --- & --- \\
\hline Gem & 0 & 0.00 & --- & --- & 8 & 0.4 & 31 & 1.3 \\
\hline Tonda di Giffoni & 33 & 0.08 & 17 & 1.5 & 17 & 0.3 & 25 & 0.6 \\
\hline Bulgaria XI-8 & 25 & 0.02 & --- & --- & --- & --- & --- & --- \\
\hline $\mathrm{LSD}_{0.05}$ & & 0.15 & & 2.2 & & 2.2 & & 1.9 \\
\hline
\end{tabular}

${ }^{\mathrm{Z}}$ Data from Pinkerton et al, 1993.

yDisease incidence calculated as percentage trees with cankers.

xTotal canker length (TCL) is least-squares mean calculated from square root transformed total canker length. 
Table 4. Numbers of ascospores of Anisogramma anomala captured by rain catch-type spore traps placed in the canopies of the potted-tree experiments and the field study.

\begin{tabular}{lcc}
\hline \hline Study & Collection period (month/d) & Spores $/ \mathrm{m}^{2} / \mathrm{d}^{\mathrm{z}}$ \\
\hline 1990 Potted trees & 2/9 to 5/6 & $2.0 \times 10^{6} \pm 1.0 \times 10^{6}$ \\
1993 Potted trees & $3 / 3$ to $5 / 27$ & $3.8 \times 10^{5} \pm 8.0 \times 10^{4}$ \\
1994 Potted trees & $3 / 1$ to $5 / 11$ & $2.7 \times 10^{5} \pm 1.4 \times 10^{5}$ \\
1993 Field plot & $3 / 3$ to 5/12 & $4.1 \times 10^{3} \pm 1.0 \times 10^{3}$ \\
1994 Field plot & 3/1 to 6/18 & $4.1 \times 10^{3} \pm 1.4 \times 10^{3}$ \\
\hline
\end{tabular}

${ }^{\mathrm{z} S p o r e}$ counts averaged over collection intervals ranging from 14 to $30 \mathrm{~d}$. Three traps were used in potted tree studies, and two were used in the field study.

reduced time ( 2 years) and expense required to obtain a first indication of the degree of quantitative resistance in a hazelnut selection. The potted-tree method provided results 16 to 24 months after exposure. In contrast, good separation of genotypes in the field plot was not obtained until 5 to 7 years. By comparing the two assays using the same clonal propagated genotypes, several limitations of the faster potted-tree testing are apparent. The potted-tree assay both overestimates and underestimates moderate quantitative resistance based on 5 years of field plot data using the same genotypes.

The field plot method may be a more reliable predictor of hazelnut disease resistance. Correlation of genotype canker length among the field study and the potted-tree experiments were positive and most were significant. There were differences, nonetheless, between the assays, particularly in the responses observed for the moderately resistant genotypes. The value of the field assay over the potted tree method is illustrated by comparison of 'Barcelona' and 'Casina'. The canker lengths of these two cultivars were not significantly different the first 3 years of the field assay and had nearly identical data in the potted tree tests. It was not until the last 2 years of the field epidemic that differences between 'Barcelona' and 'Casina' became apparent. The higher susceptibility of 'Casina' compared to 'Barcelona' in the field test is in agreement with observations made in commercial orchards in the Pacific Northwest (S.A. Mehlenbacher, unpublished data). The highest levels of quantitative resistance were exhibited in the field assay in the cultivars Bulgaria XI-8, Gem, Camponica, Tombul Ghiaghli, and Tonda di Giffoni. These genotypes appear to have the ability to sustain their growth and produce nuts after disease has been established (S.A. Mehlenbacher, unpublished data).

Year-to-year variation of the potted-tree assay needs to be considered, limiting the conclusions of the potted-tree method. More rapid appearance of symptoms (cankers) would be expected, given the higher inoculum availability and the supplemental overhead irrigation which provided an ideal infection environment in the potted-tree assays. The environmental sensitivity of the disease (Pinkerton et al., 1998a, 1998b) and the higher inoculum dose over the field assay suggests testing of selections in a minimum of two potted-tree assays would be prudent. The time required would still be reduced over the field plot assay (4 years vs. 7 years) and reliability would be improved for assessing the level of quantitative resistance in hazelnut selections.

We conclude that the potted-tree assay is useful for evaluating hazelnut germplasm. At a minimum, the potted-tree method allows for identification of genotypes with very high levels of quantitative resistance such as 'Tonda di Giffoni' and 'Gem'. Future screening of selections should always include several cultivars with well characterized responses to eastern filbert blight. The addition of these cultivars will aid in the interpretation of the year-to-year variations in disease data due to environmental factors affecting spore release and infection conditions. The field plot method showed year-to-year disease progression and is a more reliable predictor of hazelnut disease responses under common production practices.

\section{Literature Cited}

Cameron, H.R. 1976. Eastern filbert blight established in the Pacific Northwest. Plant Dis. Rpt. 60:737-740.

Coyne, C.J., S.M. Mehlenbacher, R.O. Hampton, J.N. Pinkerton, and K.B. Johnson. 1996. Use of ELISA to rapidly screen hazelnut for resistance to eastern filbert blight. Plant Dis. 80:1327-1330.

Coyne, C.J., S.M. Mehlenbacher and D.C. Smith. 1998. Sources of resistance to eastern filbert blight. J. Amer. Soc. Hort. Sci. 123:253-257.

Davison, A.D. and R.M. Davidson, Jr. 1973. Apioporthe and Monochaetia cankers reported in western Washington. Plant Dis. Rptr. 57:522-523.

Gottwald, T.R. and H.R. Cameron. 1980. Disease increase and the dynamics of spread of canker caused by Anisogramma anomala in European filbert in the Pacific Northwest. Phytopathology 70:1087-1092.

Hansche, P.E. 1983. Response to selection, p. 154-171. In: J.N. Moore and J. Janick (eds.). Methods in fruit breeding. Purdue Univ. Press, West Lafayette, Ind.

Johnson, K.B., J.N. Pinkerton, S.M. Gaudreault, and J.K. Stone. 1994. Infection of European hazelnut by Anisogramma anomala: Site of infection and effect of host developmental stage. Phytopathology 84:14651470 .

Johnson, K.B., J.N. Pinkerton, S.A. Mehlenbacher, J.K. Stone, and J.W. Pscheidt. 1996. Eastern filbert blight of European hazelnut: It's becoming a manageable disease. Plant Dis. 80:1308-1316.

Mehlenbacher, S.A. 1991. Hazelnuts (Corylus). In: J.N. Moore and J.R. Ballington (eds.). Genetic resources of temperate fruit and nut crops. Acta Hort. 290:791-836.

Mehlenbacher, S.A., M.M. Thompson, and H.R. Cameron. 1991. Occurrence and inheritance of resistance to eastern filbert blight in 'Gasaway' hazelnut. HortScience 26:410-411.

Osterbauer, N.K. 1996. Genetic variation in the eastern filbert blight pathosystem. PhD diss. abstr. 96-34071. Ore. State Univ., Corvallis.

Osterbauer, N.K., K.B. Johnson, S.A. Mehlenbacher, and T.L. Sawyer. 1997. Analysis of resistance to eastern filbert blight in Corylus avellana. Plant Dis. 81:388-394.

Pinkerton, J.N., K.B. Johnson, S.A. Mehlenbacher, and J.W. Pscheidt. 1993. Susceptibility of European hazelnut clones to eastern filbert blight. Plant Dis. 77:261-266.

Pinkerton, J.N., K.B. Johnson, J.K. Stone, and K.L. Ivors. 1998a. Factors affecting the release of ascospores of Anisogramma anomala. Phytopathology 88:122-128.

Pinkerton, J.N., K.B. Johnson, J.K. Stone, and K.L. Ivors. 1998b. Maturation and seasonal discharge pattern of ascospores of Anisogramma anomala. Phytopathology 88:1165-1173.

Pinkerton, J.N., K.B. Johnson, K.T. Theiling, and J.A. Griesbach. 1992. Distribution and characteristics of the eastern filbert blight epidemic in western Oregon. Plant Dis. 76:1179-1182.

SAS Institute, Inc. 1990. SAS procedures guide. version 6, 3rd ed. SAS Inst., Inc., Cary, N.C.

SAS Institute, Inc. 1988. SAS/STAT user's guide. release 6.03 edition. SAS Inst., Inc., Cary, N.C.

Simmonds, N.W. 1983. Strategy of disease resistance breeding. FAO Plant Protection Bul. 31:2-10.

Steel, R.G.D. and J.H. Torrie. 1980. Principles and procedures of statistics: A biometrical approach. 2nd ed. McGraw Hill, New York.

Stone, J.K., K.B. Johnson, J.N. Pinkerton, and J.W.Pscheidt. 1992. Natural infection period and susceptibility of vegetative seedlings of european hazelnut to Anisogramma anomala. Plant Dis. 76:348-352.

Westwood, M.N. 1993. Temperate-zone pomology, physiology and culture. 3rd ed. Timber Press, Portland, Ore. 